\title{
Pengaruh konsumsi semangka (Citrullus lanatus) dalam menurunkan indeks debris pada anak usia 8-10 tahun
}

\author{
${ }^{1}$ Rafi Lusnarnera \\ ${ }^{2}$ Lydia E. N. Tendean \\ ${ }^{3}$ Paulina N. Gunawan \\ ${ }^{1}$ Kandidat Skripsi Program Studi Pendidikan Dokter Gigi Fakultas Kedokteran \\ ${ }^{2}$ Bagian Biologi Fakultas Kedokteran \\ ${ }^{3}$ Program Studi Pendidikan Dokter Gigi Fakultas Kedokteran \\ Universitas Sam Ratulangi Manado \\ Email: rafi_02@rocketmail.com
}

\begin{abstract}
Fresh fruit consumption which is rich in vitamins, minerals, fibers, and water can expedite tooth self cleansing, therefore, debris width surface can be decrease. Watermelon is one of favorable fruits with sweet taste. Watermelon contains $91.45 \mathrm{~g}$ water and $0.4 \mathrm{~g}$ fiber every $100 \mathrm{~g}$ of watermelon flesh. Debris affects the occurrence of caries. According to Basic Health Research (RISKESDAS) in 2013, dental and oral health problems, specifically in North Sulawesi, were $31.6 \%$; caries in North Sulawesi was 5.4\%. Preventive efforts towards caries among children must be done systematically and as early as possible. Age category $8^{\text {th }}-10^{\text {th }}$ is the most critical on the occurrence of caries. This study aimed to find out whether watermelon consumption can decrease debris index among children aged 8-10 years old. This was an experimental study with a preexperimental design one-shot case study and a pre-test and post-test approach. This study was conducted at SDN 118 Manado, with a total population of 38 students. Samples were obtained by using the total sampling method. Based on the Wilcoxon test, the significance probability value was $p=0.000$ which meant that there was a significant difference between debris index before and after watermelon consumption. Conclusion: Watermelon consumption can decrease debris index among children aged 8-10 years.
\end{abstract}

Keywords: watermelon, debris index, children

\begin{abstract}
Abstrak: Konsumsi buah yang segar dan kaya akan vitamin, mineral, serat dan air dapat melancarkan pembersihan sendiri pada gigi, sehingga luas permukaan debris dapat dikurangi. Semangka merupakan buah yang banyak disukai karena rasanya yang manis. Dalam semangka terkandung kadar air yang cukup tinggi yaitu 91,45 g dan kadar serat sebesar 0,4 gr tiap $100 \mathrm{~g}$ daging buah semangka. Debris berpengaruh cukup besar terhadap proses terjadinya karies. Berdasarkan Riset Kesehatan Dasar (RISKESDAS) pada tahun 2013, masalah gigi dan mulut khususnya di Provinsi Sulawesi Utara sebesar 31,6\%, dan yang mengalami karies gigi sebesar $5,4 \%$. Upaya preventif pada anak diperlukan untuk mengatasi karies gigi serta dilakukan secara sistematis dan sedini mungkin. Usia 8-10 tahun merupakan kelompok usia yang kritis terhadap terjadinya karies gigi. Penelitian ini bertujuan untuk mengetahui pengaruh mengonsumsi semangka dalam menurunkan indeks debris pada anak usia 8-10 tahun. Penelitian ini menggunakan metode eksperimental dengan rancangan pra-eksperimental jenis one-shot case study dan pendekatan pre dan post-test perlakuan. Penelitian ini dilaksanakan di SDN 118 Manado dengan populasi sebanyak 38 siswa. Sampel penelitian ini didapatkan dengan teknik total sampling. Berdasarkan uji Wilcoxon nilai probabilitas signifikansi $\mathrm{p}=0,000$ yang artinya terdapat perbedaan bermakna antara selisih indeks debris sebelum konsumsi semangka dan setelah konsumsi semangka. Simpulan: Konsumsi semangka dapat menurunkan indeks debris pada anak usia 8-10 tahun.

Kata kunci: buah semangka, indeks debris
\end{abstract}


Konsumsi buah yang segar dan kaya akan vitamin, mineral, serat dan air dapat melancarkan pembersihan sendiri pada gigi, sehingga luas permukaan debris dapat dikurangi dan pada akhirnya karies gigi dapat dicegah. ${ }^{1}$ Semangka merupakan buah yang banyak disukai karena rasanya yang manis, mudah di dapat dan merupakan tanaman sumber vitamin, mineral, serat, dan mengandung enzim. Dalam semangka terdapat kadar air yang cukup tinggi yaitu sebesar 91,45 g dan terdapat kadar serat sebesar 0,4 g tiap $100 \mathrm{~g}$ daging buah semangka. ${ }^{2}$

Salah satu faktor pendukung yang menyebabkan terjadinya karies gigi yaitu debris atau sisa-sisa makanan yang terdapat di sekitar gigi. Debris adalah material lunak yang terdapat pada permukaan gigi yang terdiri dari lapisan biofilm, material alba, dan sisa makanan. Debris mempunyai pengaruh yang cukup besar terhadap proses terjadinya karies. ${ }^{3}$ Luas permukaan debris dapat diukur dengan indeks debris. Indeks debris adalah skor debris yang menempel pada permukaan gigi penentu. Pengukuran indeks debris ini dilakukan untuk mengukur permukaan gigi yang ditutupi oleh debris. ${ }^{1}$

Di Indonesia kesehatan gigi dan mulut merupakan hal yang perlu mendapat perhatian serius dari pemerintah dan tenaga kesehatan gigi. Hal ini disebabkan karena tingginya angka kejadian masalah gigi dan mulut di Indonesia, yakni sekitar 90\% penduduk menderita penyakit gigi dan mulut. ${ }^{4}$ Berdasarkan Riset Kesehatan Dasar (RISKESDAS) pada tahun 2013, masalah gigi dan mulut khususnya di Provinsi Sulawesi Utara sebesar 31,6\% dan yang mengalami karies gigi di Sulawesi utara sebesar 5,4 \%. ${ }^{5}$

Upaya preventif pada anak diperlukan untuk mengatasi karies gigi, dilakukan secara sistematis dan sedini mungkin yaitu pada usia muda. Usia 8-10 tahun merupakan kelompok usia yang kritis terhadap terjadinya karies gigi dan mempunyai sifat khusus yaitu transisi pergantian gigi susu ke gigi permanen. Pemilihan murid Sekolah Dasar sebagai objek Usaha Kesehatan Gigi Sekolah
(UKGS) sangat penting mengingat kurangnya perhatian akan kesehatan gigi anak usia sekolah dasar dan pada dasarnya anak usia ini sangat peka terhadap pendidikan baik dari perilaku maupun pola kebiasaan dan dalam pertumbuhan masih dapat diperbaiki. ${ }^{6,7}$ Penelitian ini bertujuan untuk mengetahui pengaruh konsumsi semangka (Citrullus lanatus) dalam menurunkan indeks debris pada anak usia 8-10 tahun.

\section{BAHAN DAN METODE PENELITIAN}

Jenis penelitian ini eksperimental dengan rancangan pra-eksperimental oneshot case study dengan pendekatan perlakuan pre dan post-test. Penelitian ini dilakukan pada bulan September 2015 di SDN 118 Manado. Populasi penelitian yaitu seluruh siswa yang berusia 8-10 tahun di berjumlah 41 siswa. Dengan menggunakan total sampling berdasarkan kriteria inklusi dan ekslusi yang telah dibuat, diperoleh sampel sebesar 38 siswa yang terdiri dari 22 perempuan dan 16 laki-laki. Penelitian dilakukan setelah mendapat izin dari pihak sekolah dan adanya surat persetujuan atau informed consent yang telah ditanda tangani oleh orang tua subjek penelitian

Pengambilan data dilakukan dengan pemeriksaan intraoral untuk mengukur indeks debris dengan cara perhitungan dari Green dan Vermillion (Tabel 1).

Tabel 1. Kriteria penghitungan indeks debris

\begin{tabular}{cl}
\hline Skor & \multicolumn{1}{c}{ Kriteria } \\
\hline 0 & $\begin{array}{l}\text { tidak terdapat debris } \\
\text { ada debris lunak menutupi tidak lebih } \\
\text { sepertiga permukaan gigi } \\
\text { adanya debris lunak menutupi lebih } \\
\text { dari sepertiga permukaan gigi, tetapi } \\
\text { tidak lebih dari dua pertiga permukaan } \\
\text { gigi. }\end{array}$ \\
3 & $\begin{array}{l}\text { ada debris di lebih dari dua pertiga } \\
\text { permukaan gigi. }\end{array}$ \\
\hline
\end{tabular}

Skor indeks debris diperoleh dengan cara menjumlahkan debris skor tiap permukaan gigi dibagi dengan jumlah gigi yang diperiksa. Kriteria indeks debris 
sebagai berikut: baik $(0,0-0,6)$, sedang $(0,7-$ 1,8), dan buruk $(1,9-3,0)$.

Instrumen yang digunakan ialah formulir pemeriksaan. Alat dan bahan yang digunakan dalam penelitian ini ialah biskuit dan buah semangka.

\section{HASIL PENELITIAN \\ Profil sekolah}

Penelitian ini dilaksanakan di SDN 118 Manado, Kelurahan Batukota, Kecamatan Malalayang, Kota Manado, Provinsi Sulawesi Utara dengan jumlah anak keseluruhan dari kelas 1- 6 sebanyak 120 anak dengdanan guru sebanyak 11 orang.

\section{Karakteristik subjek penelitian}

Jumlah populasi sebanyak 41 responden, namun yang memenuhi kriteria inklusi berjumlah 38 responden. Berdasarkan hasil penelitian diperoleh gambaran distribusi karakteristik responden berdasarkan jenis kelamin dan gambaran distribusi karakteristik responden berdasarkan berdasarkan usia.

Distribusi karakteristik responden berdasarkan jenis kelamin dapat dilihat pada Tabel 2 yang menunjukkan responden dengan jenis kelamin perempuan berjumlah 16 responden $(41,1 \%)$ dan responden lakilaki berjumlah 22 responden (57,9\%).

Tabel 2. Distribusi karakteristik responden berdasarkan jenis kelamin

\begin{tabular}{ccc}
\hline Jenis & $\mathrm{N}$ & $\%$ \\
Kelamin & & \\
\hline Perempuan & 16 & 42,1 \\
Laki-laki & 22 & 57,9 \\
Total & 38 & 100 \\
\hline
\end{tabular}

Tabel 3. Distribusi karakteristik responden berdasarkan usia

\begin{tabular}{ccc}
\hline Usia (Tahun) & $\mathrm{N}$ & $\%$ \\
\hline 8 Tahun & 15 & 39,5 \\
9 Tahun & 9 & 23,7 \\
10 Tahun & 14 & 36,8 \\
Total & 38 & 100 \\
\hline
\end{tabular}

Data pada Tabel 3 menunjukkan bahwa distribusi karakteristik responden terendah berdasarkan usia sebanyak 9 responden
(23,7\%) berusia 9 tahun dan dan responden tertinggi sebanyak 15 responden $(39,5 \%)$ berusia 8 tahun.

\section{Hasil pemeriksaan indeks debris sebelum dan sesudah mengonsumsi semangka}

Hasil penelitian pemeriksaan indeks debris dengan menggunakan cara perhitungan Green dan Vermillion. Pemeriksaan indeks debris dibagi menjadi dua yaitu pemeriksaan indeks debris sebelum mengkonsumsi semangka dan pemeriksaan indeks debris sesudah mengkonsumsi semangka.

Data pada tabel 4 menunjukkan Indeks debris sebelum mengkonsumsi semangka, responden yang berada dalam kategori baik tidak ada (0\%), berada dalam kategori sedang 21 responden (55,3\%) dan yang berada dalam kategori buruk 17 responden (44,7\%).

Tabel 4. Hasil pemeriksaan indeks debris sebelum mengkonsumsi semangka

\begin{tabular}{ccc}
\hline Kategori & $\mathrm{N}$ & $\%$ \\
\hline Baik & 0 & 0 \\
Sedang & 21 & 55,3 \\
Buruk & 17 & 44,7 \\
Total & 38 & 100 \\
\hline
\end{tabular}

Data pada Tabel 5 menunjukkan Indeks debris sesudah mengkonsumsi semangka, berada dalam kategori baik 23 responden (60,5\%) dan dalam kategori sedang 15 responden (39,5\%); tidak ada responden yang berada dalam kategori buruk.

Tabel 5. Hasil pemeriksaan indeks debris sesudah mengkonsumsi semangka

\begin{tabular}{ccc}
\hline Kategori & $\mathrm{N}$ & $\%$ \\
\hline Baik & 23 & 60,5 \\
Sedang & 15 & 39,5 \\
Buruk & 0 & 0 \\
Total & 38 & 100 \\
\hline
\end{tabular}

\section{Pengaruh konsumsi semangka dalam menurunkan indeks debris \\ Hasil analisis menggunakan uji} Wilcoxon menunjukkan terdapat perbedaan indeks debris sebelum dan sesudah 
mengonsumsi semangka $\mathrm{p}<0,05$

Tabel 6. Hasil analisis uji Wilcoxon

\begin{tabular}{|c|c|c|c|c|}
\hline & $\mathrm{N}$ & $\begin{array}{l}\text { Median } \\
\text { (min-max) }\end{array}$ & $\begin{array}{c}\text { Rerata } \\
\pm \text { s.b }\end{array}$ & P \\
\hline $\begin{array}{l}\text { Indeks debris } \\
\text { sebelum } \\
\text { konsumsi }\end{array}$ & 38 & $1,8(1,5-2,3)$ & $\begin{array}{c}1,85 \pm \\
0,27\end{array}$ & 0,000 \\
\hline $\begin{array}{l}\text { Indeks debris } \\
\text { sesudah } \\
\text { konsumsi } \\
\text { semangka }\end{array}$ & 38 & $0,6(0,3-1,6)$ & $\begin{array}{c}0,70 \pm \\
0,27\end{array}$ & \\
\hline
\end{tabular}

\section{BAHASAN}

Data dari hasil penelitian menunjukkan bahwa dari 38 responden, jumlah responden laki-laki lebih tinggi dari responden perempuan yaitu 22 responden (57,9\%). Dilihat dari usia, responden usia 8 tahun lebih tinggi dari responden 9 dan 10 tahun yaitu 15 responden (39,5\%). Data tabel 3 data menunjukkan indeks debris sebelum mengkonsumsi semangka yang berada dalam kategori sedang berjumlah 21 responden (55,3\%), setelah mengkonsumsi semangka indeks debris mengalami pendurunan menjadi 15 responden (39,5\%) dengan kategori sedang. Ini menunjukan bahwa sebelum mengkonsumsi semangka lebih dari setengah responden memiliki indeks debris dalam kategori sedang kemudian mengalami penurunan setelah mengkonsumsi semangka.

Rata-rata selisih indeks debris sebelum konsumsi semangka sebesar 1,85 dan setelah mengonsumsi semangka rata-rata indeks debris sebesar 0,70. Berdasarkan uji Wilcoxon nilai probabilitas signifikansi $\mathrm{p}=0,05$ yang artinya terdapat perbedaan yang bermakna antara selisih indeks debris sebelum konsumsi semangka dengan setelah konsumsi semangka. Dengan demikian $\mathrm{H}_{0}$ ditolak dan $\mathrm{H}_{1}$ diterima. Hal ini menunjukkan terdapat pengaruh konsumsi semangka terhadap penurunan indeks debris pada anak usia 8-10 tahun. Hasil penelitian ini serupa dengan hasil penelitian yang dilakukan oleh Mandalika yang menunjukan ada selisih indeks debris sebelum konsumsi buah dengan sesudah mengonsumsi buah. ${ }^{8}$ Hasil penelitian ini juga mendukung teori yang menyebutkan bahwa buah-buahan dan sayuran berserat memiliki daya membersihkan gigi sendiri atau sering disebut self cleansing effect. Dalam penelitian lain disebutkan bahwa mengunyah makanan yang bertekstur keras, kasar, dan berserat, seperti buah-buahan dan sayuran dapat menstimulasi aliran saliva, dimana hal ini dapat meningkatkan pembersihan makanan dan mengurangi retensi makanan di rongga mulut. ${ }^{9}$

Berdasarkan hasil penelitian ini dapat dikatakan bahwa buah semangka berpengaruh terhadap penurunan indeks debris. Serat yang terkandung di dalam buah semangka merupakan pembersih alamiah pada permukaan gigi geligi, dan juga dapat membantu menyingkirkan partikel-partikel makanan dan gula selama proses pengunyahan. Serat berperan untuk meningkatkan intensitas pengunyahan dalam mulut, sehingga proses pengunyahan makanan berserat ini akan merangsang dan meningkatkan produksi saliva. ${ }^{10}$

Fungsi utama saliva yang nyata ialah pada proses mekanisme makanan, membantu membentuk bolus makanan dan memproduksi amilase untuk mencerna serat. Kandungan saliva yaitu bikarbonat dan sulfat memberi efek bufer yaitu berfungsi mengurangi keasaman plak. Plak yang bersifat asam akan memudahkan bakteri untuk melakukan proses mineralisasi yang berakibat pada penipisan lapisan email. Pembersih mulut mengurangi potensi melekatnya makanan sebagai pelarut atau pelumas, mengandung antibodi dan antibakteri, sehingga dapat mengendalikan beberapa pertumbuhan bakteri di mulut. ${ }^{11}$

Pada anak diberikan makan yang berserat seperti buah-buahan dan sayursayuran karena makanan ini dapat membantu pembersihan gigi dan selain itu juga merangsang pertumbuhan tulang rahang sehingga dapat mengurangi kemungkinan terjadinya pertumbuhan gigi yang berjejal-jejal. Makanan berserat perlu dikunyah lebih lama. Gerakan mengunyah 
dapat merangsang pengeluaran saliva lebih banyak. Di dalam saliva terkandung zat-zat seperti substansi antibakteri, senyawa glikoprotein, kalsium, dan fluorida yang sangat berguna melindungi gigi. Dalam hal ini saliva akan membasuh gigi dari zat-zat makanan yang menempel dan menetralkan zat-zat asam sehingga terhindar dari proses demineralisasi atau kerusakan gigi. Perubahan diet merupakan salah satu hal yang harus diperhatikan untuk mencegah penyakit gigi. Tujuannya untuk mengurangi baik jumlah konsumsi gula. Salah satu cara untuk mencegah timbulnya penyakitpenyakit seperti karies, karang gigi, ginggivitis, periodontis adalah dengan makan buah-buahan berserat sebagai pencuci mulut. Contoh dari buah-buahan berserat adalah pepaya, semangka, dan apel yang merupakan buah-buahan yang mudah dijumpai dan dapat langsung dikonsumsi dalam keadaan segar. ${ }^{12}$

Tindakan yang dilakukan untuk mencegah karies gigi dan radang penyangga gigi ialah memelihara kebersihan gigi dan mulut, memperkuat gigi dengan mineral, dan mengatur pola makanan. Salah satu cara mengatur pola makanan yaitu dengan memperbanyak makan makanan berserat berair seperti sayuran dan buah-buahan. Buah berserat berair tersebut dapat mengakibatkan pembersihan gigi geligi (self cleansing effect), karena pada waktu menguyah akan terjadi pergeseran serat-serat sehingga dapat melepaskan sisa-sisa makanan yang melekat pada permukaan gigi dengan pengunyahan akan merangsang sekresi saliva. Semangka memiliki kadar air dan serat yang tinggi sehingga diharapkan dengan mengkonsumsi semangka dapat terjadi penurunan debris dan perubahan $\mathrm{pH}$ saliva. $^{13}$

\section{SIMPULAN}

Berdasarkan hasil penelitian dan bahasan dapat disimpulkan terdapat pengaruh konsumsi semangka dalam menurunkan indeks debris pada anak usia 8-10 tahun

\section{SARAN}

Khususnya bagi masyarakat untuk dapat mencegah terjadinya karies gigi dianjurkan mengkonsumsi buah yang mengandung serat dan air seperti semangka.

Bagi institusi kesehatan adanya partisipasi dari tenaga kesehatan di puskesmas dalam program promosi kesehatan gigi dan mulut mengenai pengaruh konsumsi buah yang mengandung serat dan air seperti semangka dapat menurunkan indeks debris dan mencegah terjadinya karies.

Bagi institusi pendidikan dan peneliti adanya penelitian lebih lanjut dengan melibatkan populasi yang lebih luas untuk mengevaluasi pengaruh konsumsi semangka dalam menurunkan indeks debris.

\section{DAFTAR PUSTAKA}

1. Darby ML, Walsh MM. Dental hygiene theory and practice (3rd ed). Canada: Saunders Elsevier, 2010; p.281-39.

2. Natural Resources Conservation Service. Classification. US Department of Agriculture. 2010 Available form: http://ndb.nal.usda.gov/ndb/foods/sho $\mathrm{w} / 2438$ ? $\mathrm{fgcd}=$ \&manu $=$ \&lfacet $=$ \&for mat $=\&$ count $=\& \max =357$ offset $=\&$ sort $=\&$ qlookup=watermelon.

3. Astuti Y. Gejala, medikasi, keluhan di mulut dan kemungkinan efek obat jangka panjang pada pasien Systemic lupus erythematosus [Online]. 2008 [cited 2014 Mar 1]; Available from: URL:lontar.ui.ac.id gfr

4. Thaja I, Sintawati FX, Yovita AT. Gambaran karies gigi permanen di beberapa puskesmas kota dan kabupaten Bandung, Sukabumi serta Bogor. Media Litbang Kesehatan. 2006; XVI(4):1-3.

5. Riset Kesehatan Dasar. Badan Penelitian dan Pengembangan Kesehatan. Jakarta: Departemen Kesehatan Republik Indonesia, 2013; p. 111-2.

6. Ami A. Pencegahan Primer pada Anak yang Berisiko Karies Tinggi. Dental Journal. 2005;38(3):130-4.

7. Herijulianti E, Indriani TS, Artini S. Pendidikan kesehatan gigi. Jakarta: EGC, 2001; p. 101-3. 
8. Mandalika WC. Pengaruh konsumsi papaya (Carica papaya) dalam menurunkan indeks debris pada anak usia 10-12 tahun di SDN 103 Manado. eGiGi. 2014;2(2):5.

9. Stegeman CA, Davis JR. The dental hygienist's guide to nutritional care (3rd ed). St Louis: Saunders Elsevier, 2010; p. 352-62.

10. Purba TR. Perilaku kebersihan gigi dan perbedaan status oral higiene [online]. 2011. [cited 2014 Feb 20]. Avalable from: URL: repository.usu.ac.id.

11. Wides C, Brody HA, Alexander CJ,
Gansky SA, Mertz EA. Long-term outcomes of a dental pot baccalaureate program: increasing dental student diversity and oral health care access. Journal of Dental Education. 2012;77(5):537-47.

12. Steinaur J, Preskill F, Robertson $\mathbf{P}$. Training medical students in intrauterine procedures using papayas. Medical Education. 2007;412(11):1099-100.

13. Machfoedz E, Zein AY. Gigi dan mulut anak-anak. Yogyakarta: Fitramaya, 2005; p. 45-8. 